\title{
Front Matter: Volume 11441
}

, "Front Matter: Volume 11441," Proc. SPIE 11441, 2019 International Conference on Optical Instruments and Technology: IRMMW-THz Technologies and Applications, 1144101 (12 March 2020); doi: $10.1117 / 12.2566268$

SDIE Event: 2019 International Conference on Optical Instruments and Technology, SPIE. 2019, Beijing, China 


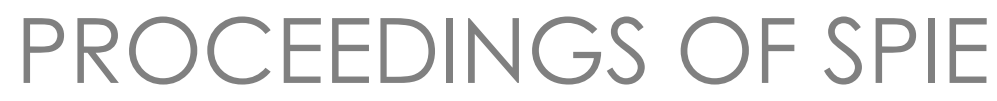

\title{
2019 International Conference on Optical Instruments and Technology \\ IRMMW-THz Technologies and Applications
}

\author{
Cunlin Zhang \\ Xi-Cheng Zhang \\ Zhiming Huang \\ Editors
}

26-28 October 2019

Beijing, China

Sponsored by

CIS-China Instrument and Control Society (China)

Cosponsored and Published by

SPIE 
The papers in this volume were part of the technical conference cited on the cover and title page. Papers were selected and subject to review by the editors and conference program committee. Some conference presentations may not be available for publication. Additional papers and presentation recordings may be available online in the SPIE Digital Library at SPIEDigitalLibrary.org.

The papers reflect the work and thoughts of the authors and are published herein as submitted. The publisher is not responsible for the validity of the information or for any outcomes resulting from reliance thereon.

Please use the following format to cite material from these proceedings:

Author(s), "Title of Paper," in 2019 International Conference on Optical Instruments and Technology: IRMMW-THz Technologies and Applications, edited by Cunlin Zhang, Xi-Cheng Zhang, Zhiming Huang, Proceedings of SPIE Vol. 11441 (SPIE, Bellingham, WA, 2020) Seven-digit Article CID Number.

ISSN: 0277-786X

ISSN: 1996-756X (electronic)

ISBN: 9781510636606

ISBN: 9781510636613 (electronic)

Published by

SPIE

P.O. Box 10, Bellingham, Washington 98227-0010 USA

Telephone +1 3606763290 (Pacific Time) · Fax +1 3606471445

SPIE.org

Copyright (c) 2020, Society of Photo-Optical Instrumentation Engineers.

Copying of material in this book for internal or personal use, or for the internal or personal use of specific clients, beyond the fair use provisions granted by the U.S. Copyright Law is authorized by SPIE subject to payment of copying fees. The Transactional Reporting Service base fee for this volume is $\$ 21.00$ per article (or portion thereof), which should be paid directly to the Copyright Clearance Center (CCC), 222 Rosewood Drive, Danvers, MA 01923. Payment may also be made electronically through CCC Online at copyright.com. Other copying for republication, resale, advertising or promotion, or any form of systematic or multiple reproduction of any material in this book is prohibited except with permission in writing from the publisher. The CCC fee code is 0277 $786 \mathrm{X} / 20 / \$ 21.00$.

Printed in the United States of America by Curran Associates, Inc., under license from SPIE.

Publication of record for individual papers is online in the SPIE Digital Library.

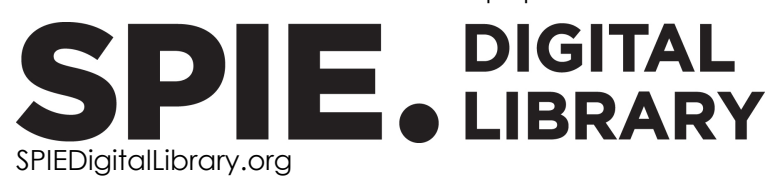

Paper Numbering: Proceedings of SPIE follow an e-First publication model. A unique citation identifier (CID) number is assigned to each article at the time of publication. Utilization of CIDs allows articles to be fully citable as soon as they are published online, and connects the same identifier to all online and print versions of the publication. SPIE uses a seven-digit CID article numbering system structured as follows:

- The first five digits correspond to the SPIE volume number.

- The last two digits indicate publication order within the volume using a Base 36 numbering system employing both numerals and letters. These two-number sets start with 00, 01, 02, 03, 04, 05, 06, 07, 08, 09, OA, OB ... 0Z, followed by 10-1Z, 20-2Z, etc. The CID Number appears on each page of the manuscript. 


\title{
Contents
}

\author{
$\checkmark \quad$ Authors \\ vii Symposium Committees \\ ix Conference Committee \\ xi Introduction \\ xiii Conference Organizers
}

IRMMW-THZ TECHNOLOGIES AND ITS APPLICATIONS

$1144102 \quad$ Non-uniformity correction technology of infrared thermal imager without shutter based on noise template [11441-1]

$1144103 \quad$ Analytical method for studying terahertz vibrations in different ginseng [11441-2]

$1144104 \quad$ Method for detecting blasting beads in cigarette filter [1 1441-3]

1144105 Terahertz wave generation from laser-induced air plasma influenced by the external electric field [11441-4]

1144106 Terahertz vortex beam generation based on complementary open rings metamaterial [11441-7]

1144107 A simple approach to generate a monochromatic plate-like THz beam [11441-9]

1144108 Temperature dependent terahertz spectroscopy of azithromycin dihydrate [11441-10]

1144109 Research on scene-based IRFPA non-uniformity correction technology [11441-11]

$11441 \mathrm{OA} \quad$ Evaluation of outputted and leaked power for a micro-cavity laser in the terahertz region [11441-14]

$11441 \mathrm{OB} \quad$ Infrared target detection and tracking based on brain-inspired model and DNNs (Invited Paper) [11441-16]

11441 OC Progress of THz traveling wave tube in IECAS (Invited Paper) [1 1441-18]

11441 OD Enhanced terahertz imaging of electronic packaging materials with deconvolution algorithm [11441-19] 
$11441 \mathrm{OE} \quad$ Flexible infrared electronic eyes for multispectral imaging with colloidal quantum dots [11441-20]

11441 OF Qualitative detection of mycelium in cordyceps powder using terahertz time-domain spectroscopy [11441-24]

$114410 \mathrm{C}$ Causality relations in analysis of diffuse reflectance spectra obtained by infrared quantum cascade laser (Invited Paper) [1 1441-30]

$11441 \mathrm{OH} \quad$ Terahertz detection of chemical analytes using a hollow core photonic crystal fiber sensor [11441-31]

114410 Investigation of typical sartan pharmaceuticals by terahertz absorption spectroscopy and density functional theory [11441-32]

$114410 \mathrm{~J} \quad$ Filtering path variable FDK (v-FDK) reconstruction algorithm for circular cone-beam CT [11441-41]

11441 OK All optically-controlled multifunctional $\mathrm{VO}_{2}$ memory device for terahertz waves [11441-42]

$11441 \mathrm{OL} \quad$ Particle filter tracking method for small infrared target based on combination of the high frequency feature [11441-44]

$114410 M \quad$ Research on terahertz non-destructive testing technology for internal defects of insulation layer [1 1 441-45] 


\section{Authors}

Numbers in the index correspond to the last two digits of the seven-digit citation identifier (CID) article numbering system used in Proceedings of SPIE. The first five digits reflect the volume number. Base 36 numbering is employed for the last two digits and indicates the order of articles within the volume. Numbers start with 00, 01, 02, 03, 04, 05, 06, 07, 08, 09, OA, OB...0Z, followed by 10-1Z, 20-2Z, etc.

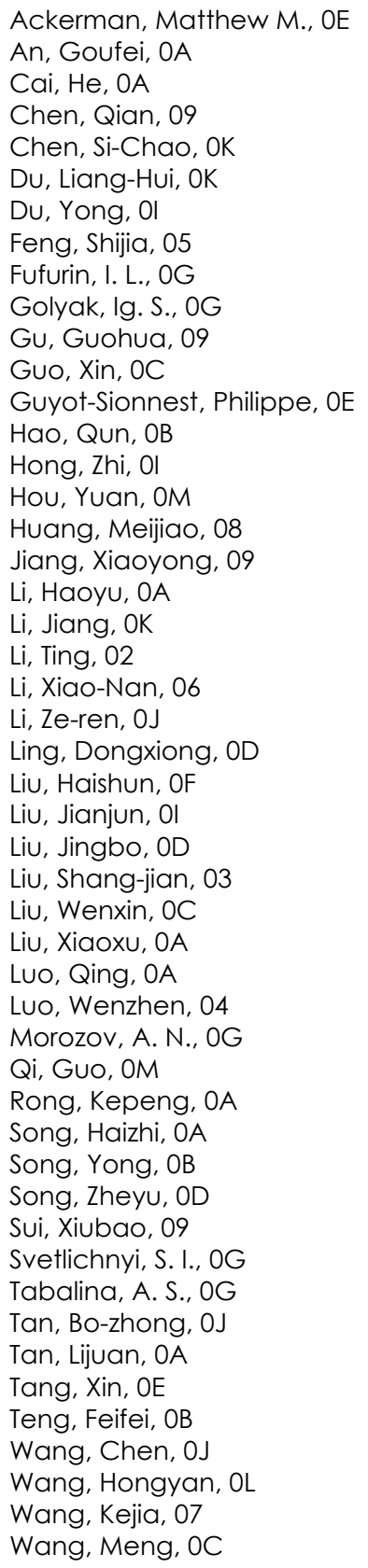


Proc. of SPIE Vol. 11441 1144101-6

\section{Downloaded From: https://www.spiedigitallibrary.org/conference-proceedings-of-spie on 26 Apr 2023
Terms of Use: https://www.spiedigitallibrary.org/terms-of-use}




\section{Symposium Committees}

Symposium Chairs

Zheng You, CIS (China), Tsinghua University (China)

Jim M. Oschmann, Ball Aerospace (United States)

Symposium Committee

Tianchu Li, National Institute of Metrology (China)

Songlin Zhuang, University of Shanghai for Science and Technology (China)

Liwei Zhou, Beijing Institute of Technology (China)

Shenghua Ye, Tianjin University (China)

Yimo Zhang, Tianjin University (China)

Guangjun Zhang, Southeast University (China)

Technical Program Chair

Guofan Jin, Tsinghua University (China)

Technical Program Co-chairs

Jinxue Wang, SPIE

Tiegen Liu, Tianjin University (China)

Local Organizing Committee Chair

Youhua Wu, China Instrument and Control Society (China)

Local Organizing Committee Co-chairs

Guoqiang Ni, Beijing Institute of Technology (China)

Qun Hao, Beijing Institute of Technology (China)

General Secretary

Tong Zhang, China Instrument and Control Society (China)

Administrative Vice General Secretaries

Yu-nan Sun, Beijing Institute of Technology (China)

Liquan Dong, Beijing Institute of Technology (China) 
Vice General Secretaries

Yuejin Zhao, Beijing Institute of Technology (China)

Cunlin Zhang, Capital Normal University (China)

Local Organizing Committee

Hongda Chen, Institute of Semiconductors, CAS (China)

Xuping Zhang, Nanjing University (China)

Shangzhong Jin, China Jiliang University (China)

Libo Yuan, Guilin University of Electronic Technology (China)

Yongcai Guo, Chongqing University (China)

Tian Lan, Beijing Institute of Technology (China)

Cuiling Li, Beijing Institute of Technology (China) 


\title{
Conference Committee
}

\author{
Conference Chairs
}

Cunlin Zhang, Capital Normal University (China)

Xi-Cheng Zhang, University of Rochester (United States)

Zhiming Huang, Shanghai Institute of Technical Physics, CAS (China)

Conference Program Committee

Peter A. Ade, Cardiff University (United Kingdom)

Jun-Cheng Cao, Shanghai Institute of Microsystem and Information Technology (China)

Hou-Tong Chen, The Center for Integrated Nanotechnologies (United States)

Jian Chen, Nanjing University (China)

Jianming Dai, University of Rochester (United States)

Jiaguang Han, Tianjin University (China)

Zhi Hong, China Jiliang University (China)

Biaobing Jin, Nanjing University (China)

Weiqi Jin, Beijing Institute of Technology (China)

Yuejin Zhao, Beijing Institute of Technology (China)

Sheng-Cai Shi, Purple Mountain Observatory (China)

Fei-jun Song, China Daheng Group, Inc. (China)

Jianmin Yuan, National University of Defense Technology (China)

Chao Zhang, University of Wollongong (Australia)

Weili Zhang, Oklahoma State University (United States)

Yan Zhang, Capital Normal University (China)

Zhuoyong Zhang, Capital Normal University (China)

Kun Zhao, China University of Petroleum (China)

YiMing Zhu, University of Shanghai for Science and Technology (China)

Conference Secretary

Zhenwei Zhang, Capital Normal University (China)

Session Chairs

1 Infrared Technologies and Applications

Zhiming Huang, Shanghai Institute of Technical Physics, CAS (China)

2 THz Technologies and Applications

Zhang Cunlin, Capital Normal University (China)

3 THz Technologies and Applications

Zeren Li, China Academy of Engineering Physics (China) 
Proc. of SPIE Vol. 11441 1144101-10

Downloaded From: https://www.spiedigitallibrary.org/conference-proceedings-of-spie on 26 Apr 2023 Terms of Use: https://www.spiedigitallibrary.org/terms-of-use 


\title{
Introduction
}

With the mutual integration of IRMMW-THz Technologies and Its Applications, they have been mutually promoted and developed rapidly. Terahertz science and technology is not only due to it has not been fully explored, but due to its promising applications in spectroscopy, imaging, communications and nondestructive testing and so on. The tremendous demand has dramatically accelerated the research and development on the smaller terahertz emitter with high-power, the uncooled terahertz detector with high sensitivity, the portable and robust devices and systems with high speed. In recent years, many reliable new signal sources, detectors, functional devices and systems continue to emerge. Terahertz technology already plays a crucial role in aerospace, biological medicine, safety inspection, nondestructive testing, cultural relics protection and next generation wireless communication. At the same time, the research and development of small power terahertz radiation source, high sensitivity uncooled $\mathrm{THz}$ detector, a portable high-speed portable equipment and system is still the key bottlenecks in technology. We are glad to see this subject attracting an increasing amount of attention and interests. Joint effort made by academia and industry combined promotes terahertz science and technology development.

In this regard, IRMMW-THz Technologies and Its Applications of OIT 2019 was organized. The conference accepted over 35 presentations from different countries/areas of the world, which focused on the novel device, system and application of IRMMW-THz science and technology, and crossed many research disciplines including plasma, metamaterials, testing and calibration, sensors, imaging and biomedical technology. We also invited renowned scholars to present their cutting-edge, covering fundamental science such as, "Progress of THz traveling wave tube in IECAS" [11441-18] and, "Infrared target detection and tracking based on brain-inspired model and DNNs" [11441-16].

\author{
Cunlin Zhang \\ Xi-Cheng Zhang \\ Zhiming Huang
}


Proc. of SPIE Vol. 11441 1144101-12

Downloaded From: https://www.spiedigitallibrary.org/conference-proceedings-of-spie on 26 Apr 2023 Terms of Use: https://www.spiedigitallibrary.org/terms-of-use 


\section{Conference Organizers}

Opto-Electronic-Mechanic Technology and System Integration Chapter, CIS (China)

Committee on Optoelectronic Technology, COS (China)

Committee on Optics, China Ordnance Society (China)

Optical Instrument Chapter, CIS (China)

Beijing Institute of Technology (China)

Tianjin University (China)

Tsinghua University (China)

Peking University (China)

Nanjing University (China)

Zhejiang University (China)

Nankai University (China)

Capital Normal University (China)

Beijing University of Posts and Telecommunications (China)

Chongqing University (China)

University of Shanghai for Science and Technology (China)

Instrument Society of America (United States)

Institute of Measurement and Control (United Kingdom)

Hong Kong Institution of Engineers (Hong Kong, China)

The Society of Measurement and Control (Japan) 
Proc. of SPIE Vol. 11441 1144101-14

Downloaded From: https://www.spiedigitallibrary.org/conference-proceedings-of-spie on 26 Apr 2023 Terms of Use: https://www.spiedigitallibrary.org/terms-of-use 